\title{
The Discursive Construction of Gender as Social Identity in Arabic written Discourse
}

\author{
Shifaa Hadi Hussein \\ Department of Translation, College of Arts, University of Tikrit, Tikrit, Iraq
}

\begin{abstract}
Identity is the idiosyncratic features that characterize an individual as being unique. It is the dynamic per formativeness of self through behaviors, acts, clothes and etc.. When such self is shared (by sharing memories, desires, and emotions) with others, it becomes social identity. Such an identity is, thus, changed, transformed, spoke out, acknowledged and never be fixed at any moment of life. The current study aims at studying the discursive construction of social identity in Arabic written discourse. It seeks to ponder the question of what linguistic devices do the Arab writers utilize to identify themselves in discourse and to show sameness and differences between in - and out- groups. To attain the above aim, we hypothesize that Arab writers use scanted discursive and linguistic devices to identify gender in their writing. Accordingly, seven linguistic and discursive components have been chosen to analyze the discourse to unveil the identity of its writer: processes, mood, modality, vocabulary and collocation, pronouns, figurative uses of language, and interdiscursivity. The study comes with some conclusions, the most important of which are: social identity can be traced in Arabic discourse through the construction of in _ and out_groups with the in-group being victimized by the out-group who is the dominant, a conclusion which clashes with studies of critical discourse analysis, and changes and transformation of identity occur through stages including: attention, interest, solutions and urging by giving commands.
\end{abstract}

Index Terms - discursive construction processes, gender, identity change, in- and out-groups, interdiscursivity, social identity.

\section{INTRODUCTION}

Identity is the idiosyncratic features that characterize an individual as being unique. It is the dynamic performativeness of self through (linguistic and non -linguistic) behaviors, acts, clothes and etc..When such self is shared (by being sharing memories, desires and motives), it becomes social identity. Such an identity is, thus, changed, transformed, spoke out, acknowledged and never be fixed at any interval of life. It is the social construction of self, " an essential, cognitive, socialized, phenomenological or psychic phenomenon that governs human actions" (Benwell and Stokoe, 2006, p. 3), that is realized by others. This identity is discursively represented since it is " actively, ongoing, and dynamically constituted in discourse"(Ibid, p 4).

So, identity answers the question of who are we to ourselves and who are we to each other being negotiated through discourse verbally or non-verbally. Identity, further, is the " emergent product rather than the pre-existing source of linguistic and... semiotic practices" (Bucholtz and Hall, 2005, p.588). This identity can be discursively realized through social interaction (see Hare-Mustin and Maracek, 1990, p.533, Kittzinger, 2000, p.170 and West and Festermaker, 1993, p.152). Accordingly, identity can be traced back in the linguistic choices participants select to accomplish their negotiation process.

The current study is conducted, thus, to answer the following questions:

1. What are the social identities that the writers try to communicate through discourse?

2. How these identities are realized linguistically and discursively in the discourse?

3. Are there any changes (or transformation) of identity that the writers try to establish through his/her discourse?

There are so many types of identity that people may accomplish in their communication; gender identity (see for example Bucholtz et al, 1999 and Cameron and Kulick, 2003), age identity (see Coupland and Nussbaum, 1993), ethnic and national identity (see Wodak et al, 1999), and identity in context (see Benwell and Stokoe, 2006)(including conversational identity, social identity, institutional identity, and spatial identity) (see also Weinreich and Saunderson, 2003).

Identity, as a term, is referred to differently in different disciples; it is referred to as: self, selfhood, position, role, personality, category, category membership, person formulation, person disposition, subjectivity, subject, agent, subject, agent, subject disposition, persona, or social actors (see Benwell and Stockoe, 2006, p. 5, Leeuwen, 1996, and Sacks, 1992).

For Taylor, 1989, the term identity (as it is nowadays used) does not exist before the end of the 15th C. and when it is first produced,it means the " internal project of self". However its first appearance goes back to exactly 1570 as "identitie"

Journal of University of Human Development

Volume 5 No. 3(2019); DOI: 10.21928/juhd.v5n3y2019.pp168-175

Regular research paper: Published 5 August 2019

Corresponding author's e-mail: shifaahissein@gmail.com

Copyright (02019 Shifaa Hadi Hussein. This is an open access article distributed under the Creative Commons Attribution License

(CC BY-NC-ND 4.0) 
meaning "the quality or condition of being the same in substance, emposition, nature, properties in particular qualities under condition, absolute or essential sameness, oneness." (Benwell and Stockoe, 2006, p.159). Taylor (1989, p. 159) believes that in the Enlightenment period, two thinkers study the term of identity; Descrates (1590-1650) and Locke (16321704). The former attaches the notion of identity with rationalism and the latter with empiricism and observation.

The best influential scholar to the term of identity in the 20th century is Freud, 1927, the father of psychoanalysis. Accordingly, identity is realized as an "over socialized conformity" (Woodward, 2002, p. 16). And here, identity is seen to be in combination with others as declared by Hall (2004, p. 51) "an individual's self-consciousness never exists in isolation... it always exists in relationship with 'other' or 'others' who serve to validate its existence". Thus, identity is realized to be social (collective) identity; i.e. "social variable against which forms of social behavior ...[including] linguistic usage could be measured". Accordingly, two types of identity can be established; personal identity and social (or collective) identity. These types are going to be the core of the next sections.

\section{Personal IDEnTity}

Personal identity is the ego or self identity according to which personal properties distinguish one individual from others. Baumeistr, (1998) believes that personal identity can be defined as "unitary and conscious awareness of who one is". Personal identity is usually studied under psychology, while social identity is studied under social psychology. Personal identity, further, is the representation of self as unique human being with its own personal experiences and body. Three theories study this view of identity from a psychological point of view; dualism, psychological theory of personal identity and the bodily theory of personal identity. With no identification of the role of body, dualism relates personal identity with the mental substance, " I do not depend on anybody in order to be and continue being me [and realizing my identity]" (Wikipedia, 2018 , p.1).The psychological theory of personal identity considers substance and the psychological properties (including experiences, emotions, memories, feelings and etc.), " what makes me me is not what body I am in, but what is distinctive about me, as a person in particular, what psychological properties I have"(ibid). The bodily theory of personal identity emphasizes that physical continuity is needed together with the psychological properties. Accordingly, in order to be the same person, "mental continuity" is needed to be "the same person"(ibid: 2). Psychological continuity, for instance, needs a brain (mental continuity) and the whole body is needed for such psychological continuity.

Relating past, present and future time in the accomplishment of personal identity, Weinreich (1986, p. 168) in an approach called "Identity Structure Analysis" (ISA), defines personal identity to be " the totality of one's self-construal in which how one construes oneself in the present expresses the continuity between how one construes oneself in the past and how one construes oneself as one aspires to be in the future". Furthermore, self and others are organized in a fixed social structure. Thus, a " structural representation of the individual's ...experience, in which the relationships between self and other agents organized in relatively stable structure overtime... with the emphasis on the socio-cultural milieu in which self relates to other agents and institutions" (Weinreich and Saunderson, 2003, p. 1).

\section{SOCIAL IDENTITY}

When personal identity is shared, it becomes social or collective identity and this is the notion of identity we cover in our paper. Social identity is first developed by Tajfel and his colleagues (see Tajfel, 1982, and Tajfel and Turner, 1986). It is related to the identification of an individual within a specific group that he chooses to be within. Social identity, thus, is " defined by individual identification with a group: a process constituted firstly by a reflexive knowledge of group membership and secondly by an emotional attachment or specific disposition to this belonging" (Taylor, 1982, p. 25). In this way, identification of in-group and out-group and their differences have a great role to play here. And conflict of different types is likely to be found accordingly. This view has been tackled in different disciplines resulting in a culminated theories and models of different perspectives all concentrating upon the realization of social identity. These disciplines include: social psychology (e.g. Taylor, 1989), anthropologyand ethnography (CA, see Sacks, 1992), philosophy, discourse analysis (Van Dijk, 1998), critical discourse analysis (Wodak et al 1999), sociolinguistics (see Coates, 2003 and 2004) and syntax (systemic functional grammar,see Benwell and Stockoe, 2006) to mention few only and as we are going to see later on.

\section{A. The Ethnographic Study of Identity:}

Many approaches emerge here to study identity from an ethnographic point of view. However, we choose only two approaches to talk about due to their significance in the development of the theory of identity in general and this paper in particular. These two approaches are membership categorization analysis and performativity.

\section{A.1. Membership Categorization Analysis}

Sacks (1972) develops an ethnographic approach to study social identity which is called membership categorization analysis (MCA). It is "the organization of common - sense knowledge in terms of the categories members employ in accomplishing their activities in and through talk" (Francis and Hester, 2004, p.21). This approach is used to study categories in interaction in different discourse genres (see Baker, 2004 and Leudar et al, 2004). Categories may include men, women, students, teachers, and etc.. Two types of membership categories devices can be realized: a set of categories and rules of application (economy rule, and consistency rule). The categories are "duplicativly organized"; having " a team-like property". Members of a category here have specific rights and obligations to each other (e.g. family members). They are, also, "indexical" in which the reference changes in context of situation (e.g. his, they, them and etc.) (see Sacks 1972).

MCA, however, does not explain which identity membership categories will be attached to a specific talk as Schegloff (1997) 
explains since " the participants' production of the world was itself informed by these particular devices" (see also Benwell and Stockoe, 2006, p. 66). Furthermore, category membership can be implicit and by relying on inference such implicitly can be unveiled (Sacks, 1972, p. 42).

\section{A.2. Performativity}

Coates (1996, 1999, 2003 and 2004) establishes another ethnographically-oriented approach, which is that of performativity. It is an approach that is concerned with the realization of social identity in masculine and feminine discourse (if we have the right to call it like that) in every day interaction (away from the grammatical use of gender; she, he, it). She selected data from recorded conversations that she made herself focusing upon the " construction of femininity" (Coates, 1999, p. 123). She concludes that girls' talk is characterized by " a range of linguistic patterns including sustained topical talk, supportive ...talk, and the frequent use of minimal responses and hedges" (Benwell and Stockoe, 2006, p. 53). Its functions are to support the friendship and relations between girls. In contrast, masculine identity focuses on topics like contests, violence, heroism, skills and etc. (ibid, p. 55). Their talks are characterized by focus on action, lack of hedging, competitive style and use of taboo language (Coates, 2003 and 2004).

However, Coates' analysis depends on the speakers' gender rather than on the discourse itself. Accordingly, such an analysis depends on "the analysts' rather than the participants' categories [realized in the discourse]" (Benwell and Stockoe, 2006 , p. 57). It depends on the analyst's intuitions about the participants' actions rather than on what they "display to each other " in the interaction. In this sense, identity is described by itself not as reflected in the discourse.

\section{B. The Study of Identity in Discourse Analysis}

In a theory of cognitive ideology, Van Dijk, (1998, p. 118) defines the notion of identity as constituting both a personal and social construct. In the episodic memory, people construct identities as being categorized in different groups which are developed and constructed from experiences; i.e. models of events (Ibid) (see Van Dijk, 1997 and 1998 and Van Dijk and Kintsch, 1983 for this term) and so it is personal construct. Identity is social because our identities are inferred from our behaviors (whether linguistic or non-linguistic; including discourses or the way we dressed, the way we laugh and etc.). So, in one way or another when our experiences are shared our identities become socially constructed.

Thus, Van Dijk realizes the two kinds of identity, personal and social. For him, personal identity refers to the "mental representation as (personal) self, as a unique human being with its own personal experiences and biology represented in acuminated mental models" (Van Dijk, 1998, p. 119 and see also, Cote and Levine, 2002).

For Van Dijk, social identity refers to the shared identity within a group. It is " a socially shared mental construct " (Van Dijk, 1998, p. 124). Both personal and social identities change and thus, the notion of identity is " a dynamic rather than a property "(Ibid , p. 121). Social identity, so, is " a shared core of self-definition ....[i.e.] a set of social representations that members consider typical for their group" (Ibid). These social representations " have indeed a discursive nature " (Ibid, p.
125). According to this, discourse is a rich area where we can trace back identity in the linguistic choices participants select to have their negation process. However, Van Dijk only theorizes his notion of identity with no application of his conception to real data although he admits himself that identity is discursively realized in discourse.

As we can see from the above survey of the identification of the discursive representation of identity, every approach has its own problem to apply. Accordingly, in the following section we will tackle the approach that we believe suits mostly to analyze the data chosen..

\section{THE MODEL ADOPTED}

In an approach to analyze identity discursively, Benwell and Stockoe, 2006 developed an eclectic model of analysis. This model stems from Systemic Functional Grammar (SFG) developed by Halliday (1994), Fairclough, (1989) and others,Critical Discourse Analysis (CDA) (specifically the discourse - historic approach developed by Wodak (1995,2002 and 2012) and some other linguistic devices that are significant in the discourse (see Benwell and Stockoe, 2006, ps. 109-116, Koller, 2009, and Kamalu and Tamunobelma, 2013).

This model, first relies on the meta- functions of language developed by Halliday, 1994; ideational, interpersonal and textual simply defined as:

1. The ideational function of language is the representation of the world by the processes and the realization of ideologies in discourse.

2. The interpersonal function is the relationship between participants and the discourse and

3. The textual function is the organization of the discourse.

Three notions are related to these three functions respectively; transitivity, mood (and modality) and theme (see Benwell and Stockoe, 2006, p.109). Transitivity is concerned with the processes that the agents do in discourse. They include: material (being related to the tangible actions conducted by actor, agent, goal or beneficiary participants), mental (being related to the actions of mind conducted by experience or phenomenon participants), relational (having a relation between the doer of the action and the complement and the doer is either carrier, attribute, token or value), verbal (related with the verb of 'saying' and the involved participants are sayer, verbiage, beneficiary, or existential (being related to process of existence with the participants involved being only existent)). All these processes occur with circumstances of time, manner and place (see Halliday, 1994, Halliday and Matthiessen, 2004, ps. 170175, Fairclough, 2003, Toolan, 1998 as well as Benwell and Stockoe, 2006).

Mood is related to choices done between declaratives, interrogatives, and imperatives. While modality refers to the use of modal verbs, participle verbs, verbs of cognition and copular verbs (see Benwell and Stockoe, 2006: 112). Theme, further, is related to notions of forgrounded and backgrounded. Another group of elements are included in this model compromising (vocabulary and collocation, figurative uses of language (including metaphor (Lackoff, 1993), metonomy, personification), presupposition, pronouns and intertextuality / interdiscursivity relations (Wodak et al 1999) (see Benwell and 
Stockoe, 2006, ps. 113-115). These terms, it should be said, are considered in relation to identity only.

It seems that Benwell and Stockoe depend on the discourse chosen to outline the elements needed in realizing identity in discourse. Thus, this model is data -based (see also Wodak et al, 1999 and Coates 2003 and 2004). So, it is applicable to find other elements which are radical in analyzing identity representation in discourse. And although Benwell and Stockeo, 2006 apply this model to conversation, we believe that such a model is applicable to written discourse. So, processes, mood, modality, vocabulary and collocation, pronouns, the figurative uses of language,intertextuality/interdiscursivity relations are going to be used as the methodological components against which the selected data are going to be analyzed to trace identity discursively. If other components are found important in the discourse, they are going to be handled.

\section{Data Analysis}

The data chosen in this paper constitute an article under the title " (On Violence Against Women) written by Nerdeen Shahada, a woman who published her article on PANET web site on 20th of January, 2018.

The article starts with a Hadeeth of the Prophet Mohammad commanding men to take care of women as an indication that the Prophet himself takes care of women and asks Muslims to do so. This forgrounding of the Hadeeth as a powerful opening of the article foreshadows that what will come is a plea for men to take care of women. The writer ends her article with an Aya from the Glorious Quraan taken from Al-Nissa Sura explaining that God Himself honors women by equalizing them with men (see appendix 1). These two poles of the article shows that the writer tries to plea men and the society to follow their religion to take care of women since Allah and His Prophet are commanding them to do so. In what follows, the components of the model adopted earlier are going to be applied.

As we can see from the data chosen, the prevailing social identity represented here is gender identity and specifically feminism as shown by the repetition of the words 'أمرأة ' (singular - the woman) and 'نساء' (plural - women). 'المراة' (the woman) has been used twenty one times, all denoting a generic reference. The word ' النساء ' has been used only five times and also, they denote generic reference. They are all used with the definite article ' $\mathrm{J}$ ' (the) to emphasize the generic reference that the woman referred to in this article is any woman and all women in the world. When the word 'نساء' ' is mentioned with no 'ال' (the), they are mentioned in collocations to have also generic reference: 'نساء العالز' (women of the world) and 'نساء المجمع ' ' (women of the society). And when the word; 'المراة' (the woman) is used in specific reference, it is used with collocations: 'المراة المعنفة' (the violated woman), 'امراة واحدة' (one woman) in away to give a statistical study of women who face violence in the world.

So, the term 'women' has been used positively, generically and being victimized by the other group who is the less prevailing social identity that the writer tries to establish in this article; that is of the 'man' who is responsible for violence against women. Interestingly, the word of 'man' is never mentioned neutrally or positively in this article. Instead, the following expressions are used 'الطرف المقرب لهن' (the close party), ' 'شريك حياتهن ' الندنب' (husband), ' (the guilty)(mentioned four times), and 'الفاعل'(the doer). All these expressions are used negatively to refer to the 'man', and when such expressions like 'husband' and 'close party' are used, they are used in co-text in association with violence as a message that the writer wants to imply that " instead of being the protector as these expressions may denote, men are the guilty who are responsible for violence" a paradox that needs to think about a lot. These expressions are only repeated four times (with the word 'the guilty' being repeated four times). All these expressions are used generically with the definite article 'al' (the) with no collocations. The negative connotation of these expressions becomes the attributes of men and make them responsible for the violence against women. The group of women, thus, is represented in this discourse as poor, having violence being exercise against whom; victims, and should inform the institutions of this violence. While, the group of men is the guilty, the doer of the action of violence and thus should be punished. In this discourse the two groups are conflicting through the linguistic choices the writer select to have her message being delivered to all women.

The third person feminine singular pronoun (her) has been used twenty four times in this discourse represented by '-ha' (e.g. حياته, her life), the third person feminine plural pronoun (their) has been used four times represented by 'نّ' (e.g. حيانهن: their life) (their) and the second person feminine singular (you) represented by 'ن' (e.g. لاتخافن, you do not be afraid) (you) has been used four times as well. The writer, in contrast, used the third person masculine pronoun only three times represented by 'o' (e.g. افع لهis his actions) (his). This statistical analysis shows first that there is a bias towards women over men. Second, the writer detaches herself from being included within those women who she believes to be weak, she thinks that she could be a leader who can lead the herd to change the current state to something better since she herself is not silent and she spoke out the problem aloud. She only used the inclusive '-na' (our) once in the whole article to indicate that she herself does not belong to that weak herb as the following example shows:

1.

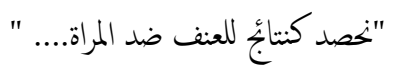

(We crop as results of violence against women......)

The writer uses the three alternatives of mood; declarative, interrogative and imperative with different degrees. The declarative mood has been used forty seven times, the interrogative five times and the imperative eight times. The use of the declarative mood shows that what is mentioned is factual, strong and convincing all directed to express the action of violence women are exposed to by men who is the guilty of that action as we can see in the following examples:

2 .

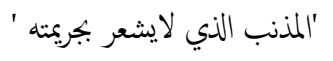

( the guilty who does not feel of his crime.) 
3. ولايعترف بها كانه فعل خاطئ حتى انه يلوم الاخرين والمراة بشكل خاص...'

(and he does not admit it as it is a wrong action and even he blames others and specifically the woman...)

'كثفت المصادر انه هنالك امراة واحدة من بين ثلاث نساء العالم تتعرض للعنف'. أنساء

(the reports reveals that there is one woman out of three in the world who is exposed to violence.)

Three interrogatives are found in the article to be rhetorical questions. These questions are used to draw the readers' attention to the problem (rather than finding solution to it).

5. ' ' الى متى ' (How long would the case be?)

6. 'فن يستطيع اذيتها؟ 'فئ (Who then can hurt her?)

These questions are posed not to seek answers but to have the readers' attention to something else. The first question is posed to give the impression that readers should start thinking of an end to that problem and the second is to give impression to the women (as a kind of encouraging) that no one can hurt her since Allah Himself honors her. The most important of the rhetorical proposed in the article is:

7. ' 'ألس كذلك ؟ 'Isn't it ?)

This rhetorical question is posed to mark the two conflicting stand points represented in this discourse; that is of the victim; women and the guilty; the man as shown in the following example:

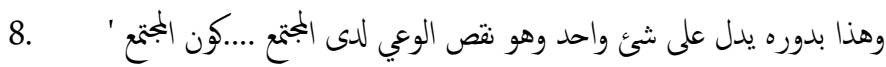

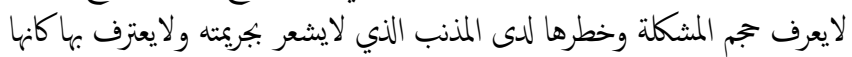

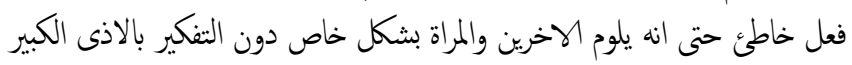

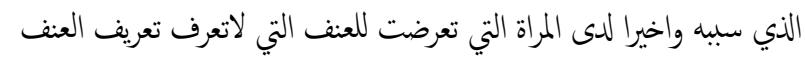

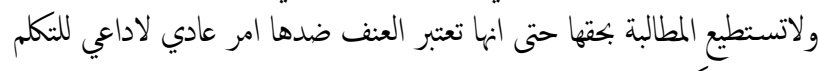

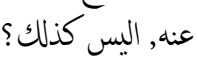

(This in turn proves one thing which is lack of consciousness on the part of the society...in that it does not realize the danger of the problem and on the part of the guilty who does not feel of his crime and does not admit it as a wrong action. He even blames others and the woman specifically for it without realizing the great harm that he causes. And on the part of the woman who is exposed to violence, who does know how to define violence and who does not know how to ask for her rights. She considers violence against her something normal, no need to talk about. Is not it?)

the two groups, the victim and the guilty on one hand and between the victim and the society, on the other hand are represented here in this example and the rhetorical question marks this conflict between them.

The other three questions are directed to the readers to encapsulate the whole article within a set of questions to find answers to and then to find solutions to the current problem The imperative mood is expressed in five sentences:
9. ' 'كفى للسكوت! (So, stop being silent!)

10.' 'كفى للعنف (Stop violence!)

11. 'كفى للالفاظ الجارحة' (Stop harmful expressions!)

12. 'حان الوقت هنالك الكثير من المؤسسات المدعومة (It is time (to change), there are plenty of supported institutions)

\section{3. لاتخافن (Do not be afraid!)}

Theses sentences are more as directives than imperatives. The writer wants to encourage her feminine audience to change their identity and be stronger to reform their reality.

Also, the writer has some uses of modality to express obligation, necessity, specification and intensification in the construction of gender identity; here femininity. This use of modality is expressed by different linguistic choices as shown in the table down (see table 1).

Table (1)

Modality in the discourse chosen.

\begin{tabular}{|c|c|c|}
\hline The samples & $\begin{array}{l}\text { Their linguistic } \\
\text { realizations }\end{array}$ & $\begin{array}{l}\text { The function of } \\
\text { modality }\end{array}$ \\
\hline 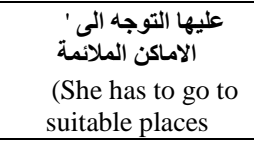 & $\begin{array}{l}\text { Prepositional } \\
\text { phrase }\end{array}$ & $\begin{array}{l}\text { Obligation /or } \\
\text { necessity }\end{array}$ \\
\hline $\begin{array}{c}\text { الاقتناع باتها هي } \\
\text { هي } \\
\text { (She has to be } \\
\text { convinced that she is } \\
\text { the stronger) }\end{array}$ & Nominal verb & Necessity \\
\hline 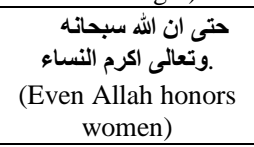 & Particle & Intensification \\
\hline 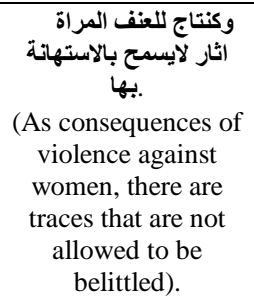 & Verbal phrase & Obligation \\
\hline $\begin{array}{c}\text { العنف بحد ذاته مشكلماعية (Violence, } \\
\text { by itself , is a social } \\
\text { problem.) }\end{array}$ & $\begin{array}{l}\text { Prepositional } \\
\text { phrase }\end{array}$ & Intensification \\
\hline $\begin{array}{l}\text { وكلها لها دور متساو الاضر. } \\
\text { (All have the } \\
\text { same role in } \\
\text { damage.) } \\
\end{array}$ & Particle & intensification \\
\hline
\end{tabular}

The particle of "حتى (even so) is used to express intensification and show astonishment by comparing two cases that the act before the article is intensified and is reintensified by the act after the article.

Some figurative use of language are detected in this discourse:

14. " موجات مغلقة من العنف" (Closed waves of violence).

"15. "نصد كنتائُ للعنف ضد المراة " 
(We harvest as results of violence agaist women.)

Consequences of violence against women become yields that need harvesting.

16. " الى ان نكسر المراة زجاج الصمت

(Till the woman breaks the class of silence.)

Silence, as a reason of violence against women is metaphorically represented as glass that the woman should break to solve the problem. It is not represented as a solid barrier to give the indication that silence is weak and for her can be broken easily.

\section{7. "(The price of the woman's silence)}

Women's silence is metaphorically represented as goods of a price to give the impression that violence against women largely depends on the woman keeping silent.

One of the interesting figurative uses of language found here is the use of the "personification" of the society to consider it responsible for the violence exposed against women as shown in the following examples:

" 18. " ويدل على نتص الوعي لدى المجتمع : "

(this proves the lack of the society's consciousness).

19. " كون المجتع لايعرف حجم المشكلة"

(that the society does know the size of the problem.)

20. " وهذا الامر يدل على الطريق السئ الذي وصل اليه المجنم ". ".

(This matter shows the bad road that the society arrives to.)

The article is, further, rich with processes of different kinds as shown in the following table (see table 2).

Table (2)

The Processes used in the selected discourse

\begin{tabular}{|c|c|c|c|}
\hline Processes & $\begin{array}{c}\text { Material } \\
\text { processes }\end{array}$ & $\begin{array}{c}\text { Mental } \\
\text { processes }\end{array}$ & $\begin{array}{c}\text { Relational } \\
\text { processes }\end{array}$ \\
\hline Verbs & 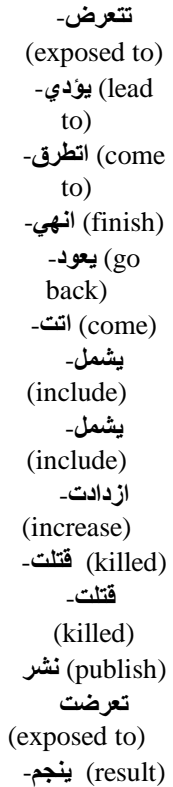 & 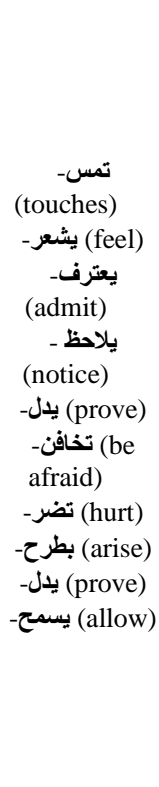 & $\begin{array}{c}\text { ستكون- (will } \\
\text { be) }\end{array}$ \\
\hline
\end{tabular}

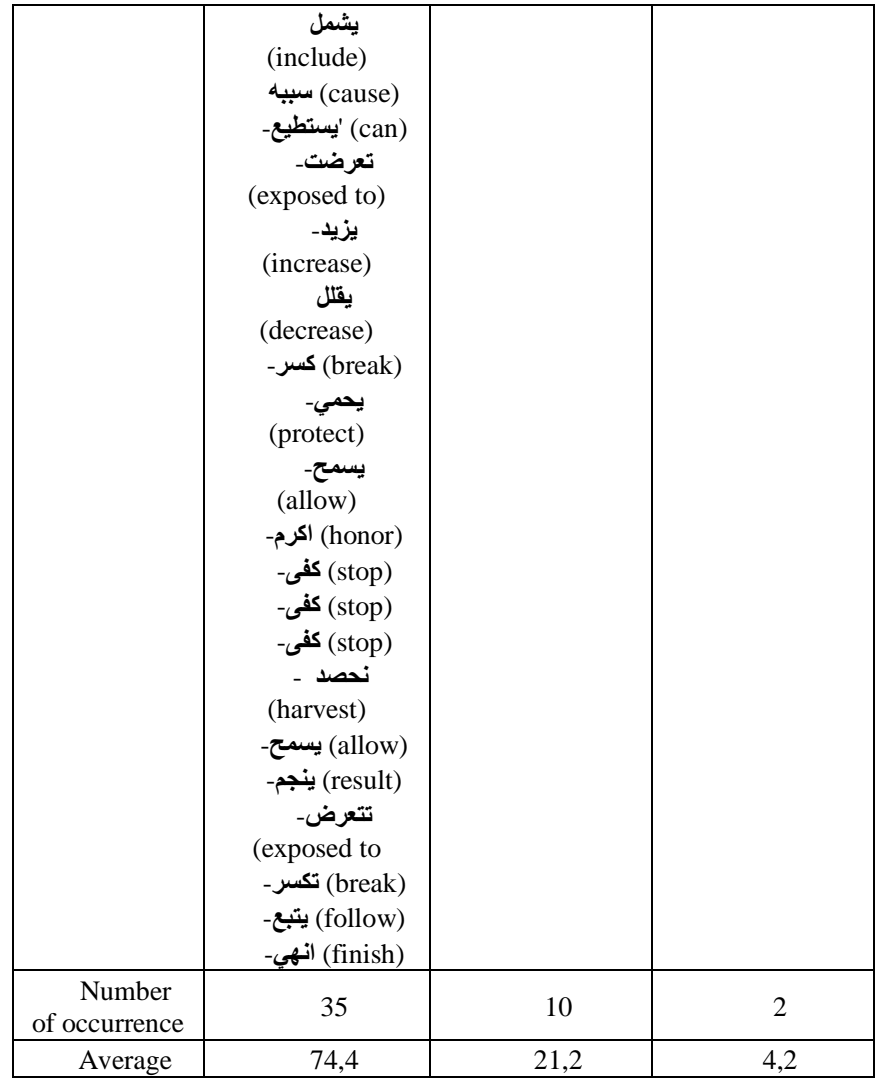

As represented in the table above, most of used process is the material with the average $(74,4 \%)$ then the mental process with the average $(21,2 \%)$ and the relational process $(4,2 \%)$. If this statistical study proves something, it proves that the writer is relying on facts and objectivity to arise her problem of violence. Her point of view is not represented in away to draw the sympathy of the outside world to the issue of violence against woman, but she states the problem of violence against women rationally and so, she is objective, rational and powerful. When the mental process is used in this article, it is always used with the identification of the woman's feeling of violence or with the emotionless feeling of the guilty:

21. المذنب الذي لايشعر بجريمته

(The guilty who does not feel of his crime.)

\section{2.! لاتخافن (Do not be afraid!)}

23. ويتلفظ بالفاظ تمس بها

(Uttering insulting words that touch her).

With the component of interdiscursivity, the writer has mentioned a report from a net site called 'vito' to refer to a statistical study that this site published; there are 17 women who has been killed last year because of violence and 82 women have been killed in the last five years also because of violence in the Arabic society. This report has been used here as a kind of evidence to prove that violence exceeds to be crimes and that the society is responsible for these crimes. This report is mention as a proof to the fact that violence is dangerous and thus, women should take care of that fact. 
Also, the notions of in-group (including women) and the outgroup (including the guilty; the man and the society) can be realized in this discourse with the first being victimized by the latter and thus creating a clear conflict between these two groups. These two groups are grouped in one sentence as illustrated in the following examples:

يشمل العنف اي اذى ستتعرض اليه المراة من قبل المذنب

(This violence includes any harm that the woman is exposed to by the guilty.)

25.

$$
\text { " المذنب يمنع المراة من التقدم ؟" - مئ }
$$

(The guilty prevents the woman from any progression).

" العنف المعنوي ويشمل هذا النوع من العنف الاستهتار من قبل المذنب " .

(The moral violence: this type of violence includes any disrespect that the guilty shows.)

The current discourse constitutes largely the discourse of feminism as illustrated by the over-use of the generic reference of the term 'women' and as illustrated by the use of labeling of the types of violence against women and its consequences. Also, there is a discursive relationship between the feminine discourse and the religious discourse as shown in the Hadeeth and the Aya picked in the discourse as we saw earlier to show that Allah and His Prophet honor women and equalize them with men. Furthermore, traces of religious discourse can be realized as the following example shows:

27.

$$
\text { فلا وجود لحت يسمح بالعنف حتى ان الله سبحانه وتعالى الزوم النساء فن }
$$

(There exists no right which allows violence that even Allah honors women who then can hurt her?)

Also, other social discourses can found to have an interdiscursive relation with the current article being represented by the mentioning of the society and the institutions:

28.

$$
\text { هنالك الكثير من المؤسسات المدعومة }
$$

\section{(There are a lot of supported institutions.)}

In the last line of the article the writer is inviting her group; women to do something by themselves; to abandon silence, violence and bad words. She is urging them to stop feeling afraid to talk and to report their problem to the institutions. This discourse can be characterized as a procedural genre to change the current weak identity of women to a strong one. The writer tries gradually to have this change of identity. First, she draw her readers attention to the danger of violence that it could exceeds to be a crime by representing facts and statistical studies. And by presenting the types of violence and its consequences, she is able to have her readers ' interest of the problem. Then, she offers some solutions to encourage them (like the institutions) and then she proposes direct commands to solve the problem and change the current status of women identity (speak out the problem). In this way, the process of the identity change has been done through the following stages: attention, interest, solution, and direct commands. When this article is published, we believe that the process of the transformation of this new identity has taken place.

\section{DISCUSSION}

One of the most interesting realizations found in the discourse chosen is that there is no involvement of the reader in the process of negotiation between the writer and his readers as this is manifested in the general use of the $3^{\text {rd }}$ person pronoun (singular and plural). Instead, the writer decides to talk about women in general (but not including herself). The only one case of the use of the second person reference is just to have the function of persuasion to alter another strong identity. Unlike the English discourse, (see for instance Koller, 2009) the Arab writers tend to use this kind of reference because they believe it is more inclusive than the second person reference and could detach themselves from any negative and weak attributes.

The collective identity shown in this discourse is feminist identity defined socially to include all women. The in- and outgroups are both defined in the discourse with a bias towards the former and with a conflict holding between them. The latter is the dominant victimizing the former, a conclusion which clashes with those of the Critical Discourse Analysis approach who always consider the in-group to be powerful and dominant (see for instance Van Dijk, 1998 and 2001). This discourse of feminism is mixed with religious, social and procedural genres of discourse.

As we can see from the above analysis, the writer adopts the feminine ideology movement that prevails in the $20^{\text {th }} \mathrm{c}$. as a reaction against oppression and injustice that women are exposed to in the society. Many institutions arise to defend women and their rights to be equalized with men as far as having independent outcome, having teaching, indulging in works and etc. just like men. It seems that the writer is one of those who are the defenders of women' rights of living.

The writer has made use of material process more than the other types of the process available which indicates that she wants to be rational, objective and strong to offer the problem and find solutions and not to draw sympathy from the others towards women. The same aim is reached at when she used declarative mood exhaustively more than the interrogative and the imperative moods. When the interrogative mood is used the rhetorical questions are selected to give the readers chance to consider the problem. The commands used, further, are more like directive than as commands. They are used to have the process of identity change. Furthermore, she has made references to some modality expressions being realized linguistically by particles, prepositional phrases, nominal verbs to express obligation, necessity, specification, and intensification all to construct the national identity of gender.

The writer selects some figurative uses of language to construct the social identity that she is trying to produce in the discourse. She has picked metaphors, foreshadowing and personification. Also, the writer tries to have the current identity being changed and transformed through specific procedures or stages . These stages include: attention, interest, solutions and direct commands and then publishing. 
The discourse analyzed constituted different types of genre of discourse in an interdiscursive relation. It includes social, religious and procedural discourse. These genres, here, have the function of constructing the social identity and trying to change it.

\section{CONCLUSIONS}

This study is conducted to study identity and specifically social identity in Arabic written discourse. According to the analysis and the discussion, the constructed identity is of the type gender and specifically feminism and it seems that this identity is traced back through the construction of in-group and out-group with the in-group being the weaker circle and victimized by the out-group which is the dominant. This conclusion clashes with the conclusions drawn by the critical discourse analysts who assume just the opposite. Different kinds of genre are realized in this discourse which all serve to construct identity in one way or another. Traces of religious and procedural genres are spotted in the discourse.

Also, it seems that the historical context when the discourse takes place has a role to play in the selection of the linguistic materials that the writer chooses to represent the collective identity. The selection of the processes, mood, modality, figurative uses of language are all directed to construct gender identity and thus it becomes possible for the analyst to trace this identity. Last, the process of the change (and transformation) of identity is managed through stages that scattered throughout the discourse. These stages include: attention, interest, solutions, and direct commands. These stages are realized in the discourse linguistically through the choices that the writer makes to accomplish this process.

The proposed model, thus, proves to be successful in analyzing the discourse chosen. Still, the components suggested proves to be open and data-basis. In the selected discourse, we spotted new figurative uses of language that the writer used to construct identity; personification and foreshadowing and metaphor.

\section{REFERENCES}

Baker, C. (2004). Membership categorization and interview accounts. In D. Silverman(ed.) Qualitative research, theory and practice, $2^{\text {nd }}$. Ed. London: SAGE.

Bausmeitr, R. (1998). The self . In D. T. Gilbert, S. T. Fiske and G. Lindzey (eds.) The handbook of social psychology. Pp. 680-740. London:SAGE.

Benwell, B. \& Stockoe, E. (2006). Discourse and identity. Edinburgh: University Press.

Bucholtz, M. \& Hall, K. (2005). Identity and interaction: A sociolinguistic cultural approach. Discourse Studies, vol. 7, pp: 585-614.

Bucholtz, M., Liang, A. \& Sutton, L. (eds.) (1999). Reinventing identities: The gendered self in discourse. Oxford: University Press.

Cameron, D. \& Kulick, D. (2003). Language and sexuality. Cambridge: University Press.

Coates, J. (1996) . Women talk. Oxford: Blackwell.

Coates, J. (1999). Changing femininities: The talk of teenage girls . in M. Bucholtz, A. Laing \& Sutton, L. (eds.) Reinventing identities: The gendered self in discourse. Oxford: University Press.

Coates, j. (2003). Men talk. Oxford: University Press.

Coates, J. (2004). Women, men and language. London: Longman.

Coupland, N. \& Nussbaum, J. (eds.) (1993). Discourse and lifespan identity. London: SAGE.
Francis, D. and Hester, S. (2004). An invitation to ethnomrthodology: Language, society and interaction. London: SAGE.

Fairclough, N. (1989). Language and power. London:Longman.

Fairclough, N. (2003) . Analyzing discourse: Textual analysis for social research. London: Routledge.

Frued, S. (1927). The Ego and the identity. London: Hogarth.

Hall, D. (2004). Subjectivity. London: Routledge.

Halliday, M. (1994). An introduction to functional grammar. London: Arnold.

Halliday \& Matthiessen, C. (2004). An introduction to functional grammar. London: Routledge.

Hare-Mustin, R. \& Maracek, J. (eds.) Making a difference: Psychology and the construction of gender. New Haven, CT: Yule University Press.

Kamalu, I. \& Tamunbelema, I. (2013). Linguistic expression of Religious Identity and ideology in selected postcolonial nigerian literature. In Canadian Social Science, Vol.9, no, 4: pp: 78-84.

Kitzinger, C. (2000). Doing feminist conversation analysis. In Feminism and Psychology, vol. 10. Pp: 163-193.

Koller, V. (2009). Analyzing collective identity in discourse: Social actors and contexts . In Revue de Semio-linguistique des texts et discous. Vol. 27, pp: 1-16.

Lackoff G. (1993). The contemporary theory of metaphor. In A. Ortony, (ed.) Metaphor and thought. Pp: 202-251.Cambridge: University Press.

Leeuwen, V. T. (1996). The representation of social actors . in C. Rosa,C. Coulthard and M. Coulthard, Texts and practices: Readings in critical discourse Analysis. London: Routledge. Pp: 32-70.

Leudar, I. Marsland, V. \& Nekvapil, J. (2004). On membership categorization: 'Us', 'Them' and ' doing violence' in political discourse. In Discourse and Society, vol. 15, pp: 243-266.

Sacks, H. (1972). An initial investigation of the usability of conversational data for doing sociology. In D. Sudnow (ed.) Studies in social nteraction. New York: Free Press.

Sacks, H. (1992). Lectures on conversation . Oxford: Blackwell

Schegloff, E. (1997). Whose text? Whose context ? In Discourse and society, Vol. 8 , no. 2, pp: $165-187$

Shahata, N. (2018). hawla Al-Aunuf dhidda Al-Nissa. PANET web site.

Tajfel, H. \& Turner, J. (1986) . The social identity theory of intergroup behavior. In S. Worchel \& Austine, W. (eds.) Psychology of intergroup relations. Chicago: Nelson.

Tajfel, H. (1982). social identity and intergroup relations . Cambridge: University Press.

Taylor, C. (1989). Sources of the self. The making of modern identity. Cambridge: University Press.

Toolan, M. (1998). Language in literature. An introduction to stylistics. London: Arnold.

Van Dijk, T, (1997). Context models and text processing. In Stamenow, M. (ed.) Language structure, discourse and the access to consciousness. Amsterdam: Benjamin.

Van Dijk, T. (1998). Ideology: A multi-disciplinary approach . London: SAGE Publications.

Van Dijk, T. (2001). Critical discourse analysis . In D. Tannen, D. Schiffrin, and $\mathrm{H}$. Hamilton (eds.) Handbook of discourse analysis. London: SAGE.

Van Dijk, T. \& W. Kintsch, W.(1983). Strategies of discourse comprehension. New York: Academic Press.

Weinreich, P. (1986). The operationalisation of identity theory in rational and ethnic relations . In Rex, J. and Mason, D. (eds.) Theories of race and ethnic relations. Cambridge: University Press.

Weinreich, P. \& Saunderson, W. (eds.) (2003). Analyzing identity: Cross cultural, social and critical contexts . London: Routledge.

West, C. \& Fenstermaker, S. (1993). Power, inequality and accomplishment of gender: An ethnomethodological view. In P. England (ed.) Theory on gender / Feminism on theory . New York: Aldive De Gruyter.

Wikipedia (2018). Identity (social science). File:///E: / identity \%20 science\% 20 Wikipedia.

Wodak, R. (1995). Critical linguistics and critical discourse analysis .InJ. Verschueren, J.O. Ostman \& J. Bloomaert (eds.) Handbook of pragmatics. Pp: 204-210. Amsterdam: Benjamins.

Wodak, R. (2002). Aspects of critical discourse analysis. Retrieved from https://www.Researchgate.net.

Wodak, R. (2012). Language, power and identity. London: SAGE.

Wodak, R., Cillia, R., Reisigl, M. \& Liebhart, K. (1999). The discursive construction of national identity. Edinburg: University Press.

Woodward, K. (2002). Understanding identity . London: Arnold 